\title{
Contributions of Florin Gheorghe Filip in Information Science and Technology
}

\author{
I. Dzitac, M.J. Manolescu
}

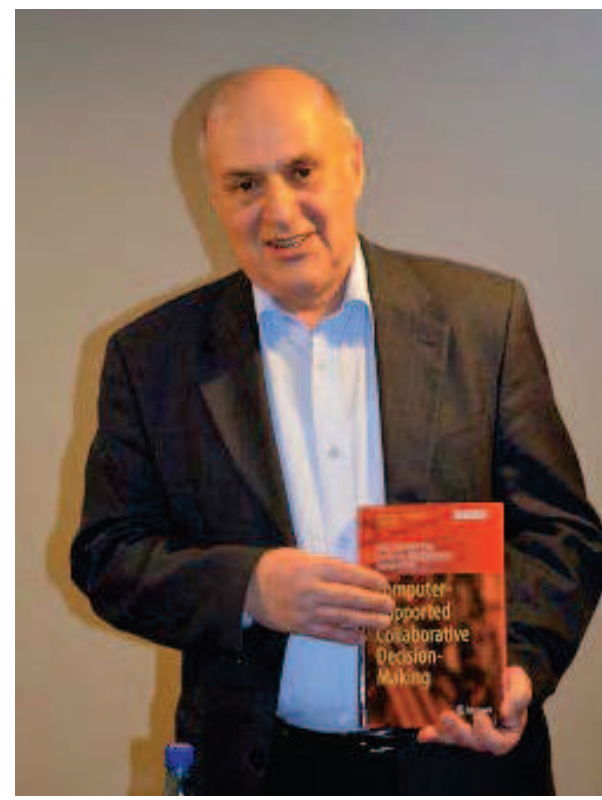

Acad. Florin Gheorghe Filip at 70 years

(Born on July 25, 1947, Bucharest, Romania)

\author{
Ioan Dzitac ${ }^{1,2}$; Misu-Jan Manolescu ${ }^{2},{ }^{*}$ \\ 1. Aurel Vlaicu University of Arad \\ 310330 Arad, Elena Dragoi, 2, Romania \\ ioan.dzitac@uav.ro,mmj@univagora.ro \\ *Corresponding author: mmj@univagora.ro \\ 2. Agora University of Oradea \\ 410526 Oradea, P-ta Tineretului 8, Romania,
}

\begin{abstract}
Romanian scientist Florin Gheorghe Filip was born in 1947 and this year he turns 70. F.G. Filip is an engineer and Ph.D. in control engineering and computer science. Still very young, he became corresponding member of the Romanian Academy in 1991 (when he was only 44 years old), and, at 52 years old (1999), become full member in the highest learned society of Romania. From 1970 to 2000, he worked at the National R\&D Institute in Informatics Bucharest (ICI). For 10 years, during 2000-2010, he was Vice President of the Romanian Academy. In 2010, he was elected President of the "Information Science and Technology" section of Romanian Academy. At present, he is the director of the Romanian Academy Library. His fields of scientific interest have been: decision support systems (DSS), large-scale systems control and optimization, technology management and foresight and IT application to cultural domain . He has authored/co-authored over 300 technical papers, 13 monographs, and edited/co-edited 24 contributed volumes.

Keywords: decision support systems (DSS), hierarchical large-scale systems, managerial activity, recognition, scientific publications.
\end{abstract}




\section{Introduction}

" To whom it may concern ...

... Dr. Filip has shown himself to be a very innovative and productive researcher whose papers are equivalent in quality and cutting-edge findings to those from the best research organizations of the world. Witness his publications in Automatica, Computers in Industry and other leading journals in the field. The establishment of Dr. Filip's stature as an internationally recognized researcher in his field and the acceptance of his work are shown by the large number of international conferences where he has served as session chairman and/or program committee member and many invited seminars he has presented in other countries ..." (T.J. Williams).

This is what Theodore J. Williams, Professor of Engineering and Director, Purdue Lab. for Applied Industrial Control, Purdue University, wrote about F.G. Filip in August 1994.

In the sequel we will highlight several aspects of Acad. Filip's professional life.

Similar works within this paper has been published in 2007, with occasion of 60 years from birth of Acad. Filip, in The Computer Science Journal of Moldova [1] and in the International Journal of Computers Communications \&s Control [8].

\section{A short biographical note}

Florin Gheorghe Filip was born on 25 of July 1947 in Bucharest, Romania. He graduated in Control Engineering from Politehnica University Bucharest (PUB) in 1970 and received Ph.D. from the same university in 1982.

In 1974, he was a guest researcher in Swedish universities (Chalmers TH in Gothenburg, Teknikum Uppsala, University of Lund, KTH, Stockholm). In 1993 and 1996 he was a visitor of German Fraunhoffer institutes: FIRST Berlin and IITB Karlsruhe, respectively. In 1983, Prof. Filip was invited to deliver a 10-day course on hierarchical control systems at Institute of Automation of the Chinese Academy of Sciences in Shenyang, China. From 2006 to 2011, he spent one month each years as a chercheur-enseignant at École Centrale de Lille (France).

He was elected as a corresponding member of the Romanian Academy (RA) in 1991 and become full member of the RA in 1999. During 2000-2010, he was Vice-president of the Academy (elected in 2000, and re-elected in 2002 and 2006). In 2010 was elected as a president of the 14th Section "Information Science and Technology" of the RA (re-elected in 2015). Also he was elected as a honorary member of Academy of Sciences of Moldova and Romanian Academy of Technical Sciences in 2007.

Prof. Filip is one of the founding members of the International Academy for IT and Quantitative Management (IAITQM), founded in 2012 at University of Nebraska in Omaha, USA. He was President of IFAC TC 5.4 SML - Large Scale Systems (2002-2008) and a member of two other IFAC technical committees: TC 4.5 (HMS), TC 5.2 (MMC) and one IFIP WG 5.12 (Enterprise Integration).

Prof Filip was the managing director of ICI- National Institute for R\&D in Informatics (19911997), and the president of Scientific Council of ICI (1995-2003). Presently, he is the director of the Romanian Academy Library.

F.G. Filip gave master courses on computer applications, expert systems, computer supported decision-making, and enterprise engineering at PUB and other Romanian universities such as Agora University Oradea, University of Bucharest, Lucian Blaga University of Sibiu, Valahia University of Targoviste, Academy of Economic Studies (ASE) Bucharest.

He has supervised doctoral studies in PUB and Institute for Artificial Intelligence (ICIA) of the Romanian Academy. Four of his former PhD students (A. Alexandru, M. Cioca, L. Duţă, 
and C.B Zamfirescu) are at present professors in various universities and supervise their $\mathrm{PhD}$ students, and C. Cândea is the leader of ROPARDO, a successful software company.

F. G. Filip was an adjunct professor at the University of the Chinese Academy of Sciences (2013-2016).

He delivered invited lectures and seminars at the invitation of universities and research centers in England (City University, London, 1985), Austria (Insbruck University, 1996), Brazil (Espirito Santo University, Vitoria, 1996), Czechoslovakia (CAS UTIA, 1983), China (University of CAS School of Management and University of Finance and Economics, Chengdu, both in 2013; CAS 2016), France (LAAS Toulouse, 1994; EC Lille, 2008), Poland (Warsaw Polytechnic University, 1980), Sweden (Chalmers TH, Göteborg, 1974 ; Uppsala University, 2011), Germany (TH Ilmenau, 1983; ZKI Berlin, 1991; Fraunhofer FIRST, 1995).

His main personal scientific interests include: hierarchical optimization and control of largescale systems, decision support systems (DSS), applications of IT in the cultural sector, technology management and foresight.

From the very beginning of his carrier he was interested to find effective solutions to real-life problems.

In 1972, as a young engineer, he was appointed to implement a teleprocessing information system in the largest steelworks in Romania, in Galaţi city (250 km away from Bucharest). He noticed the very high length of the lines which were to connect the central computer to the terminals placed in various production sections and decided to devise an algorithm based on graph theory to minimize the total length and, consequently, the costs.

While as a guest researcher in the Royal Technical University (KTH) Stockholm, in 1974, devised an efficient heuristic algorithm. Then, he approached many practical process and production control problems he identified in various industries (mainly refineries, chemical plants, water systems, discrete part manufacturing), tried to find adequate scientific methods to solve them and then came back to applications with a view to deploying the corresponding computerized devised algorithms.

Prof. Filip was an IPC member of more than 50 international conferences held in Europe, USA, South America, Asia and Africa. Since 2008 he has been the IPC chair of International Conference on Computers Communications and Control. Also chaired the IPC of several other conferences held in Chile (2008), France (2010), Romania (2006, 2007, 2008, 2009, 2010, 2012, 2014, 2016), Portugal (2010), Germany (2015). He is one of the honorary chairs of the ITQM (Information Technology and Quantitative Management). He was invited to deliver plenary talk at scientific conferences held in England (LISS2013, Reading), Chile (IFAC MCPL2004, University of the Americas, Santiago, IFAC Workshop on Logistics, Santiago, IEEE CESA2012, Santiago), China (CESA2005, University Tzinghua Beijing, ITQM2013, Suzhou), France (CSCS2013, Villeneuve d'Asq), Portugal (IFAC MCPL2010, Coimbra), Spain (IFAC BASYS2010, Valencia; CIO2012, Vigo), Tunisia (CESA1997, Hammamet).

\subsection{Several professional highlights}

1. Creating of one of the first Romanian CAD (Computer Aided Design) packages, containing original optimization algorithms in graphs called OPTCONF - Designing Equipment Configurations (1974);

2. Designing the first Romanian experimental Decision Support Systems for a steady and discreet production management, with a demonstration of their operation in teleprocessing mode at the World Cybernetics Conference in Bucharest (1976) (on the FELIX256 computer placed in ICI connected to the IBM VT 52 terminal and CII MITRA minicomputer, located at the Sala Palatului (Palace Hall); 


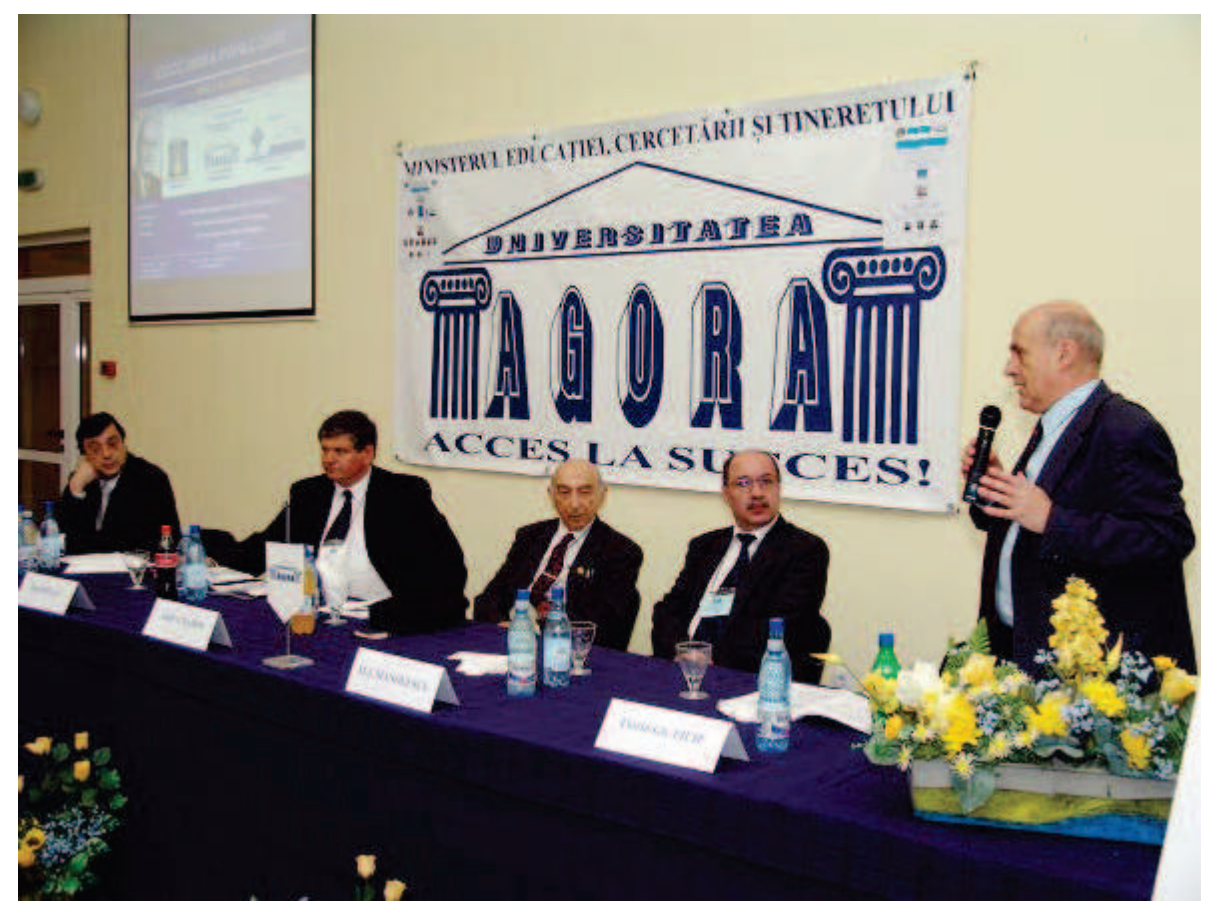

D. Tufis, I. Dzitac, L.A. Zadeh M.J. Manolescu, F.G. Filip (ICCCC2008, Oradea)

3. Coordination of teams who built DISPATCHER DSS family (containing original optimization algorithms for discrete time systems with hard constraints, sparse matrices, and slowly variable in time parameters) implemented in refineries, chemical plants and retention and distribution water systems (1980-2000).

4. Refining, adapting, and using control theory methods to model the interacting entities of the cultural sector and creative industries (since 1996).

\subsection{Recognitions and awards}

Prof. Filip is a Honorary Magister of Dunărea de Jos University of Galaţi (since 2006), a honorary member of the Agora University Senate (since 2007) and has received Doctor Honoris Causa title from Lucian Blaga University of Sibiu (November 2000), Valahia University, Târgovişte (2007), Ovidius University, Constanta (2007), Ecole Centrale de Lille, France (2007), Politehnica University of Timişoara (2009), Agora University of Oradea, Academy of Economic Studies of Bucharest (2014), University Petrol-Gaze of Ploieşti (2017), and University of Piteşti (2017).

Prof. Filip received the National Orders "Serviciu Credincios" (Contentious Service), at rank of "Great Cross" and "Steaua Romaniei" (Star of Romania) at rank of "Knight" from the presidents of Romania in 2000 and 2017 , respectively, and "Marin Drimov" medal from the Bulgarian Academy of Sciences. He is the recipient of several prizes such as: COPY RO Prize for the best book in IT for the book "Computer aided decision-making" (in 2002), the Grigore Moisil Prize, and Medal "Man of the year 1999" from the Association for Economic Informatics, "W. Scott Jr. in IT" Award from the IAITQM for "remarkable record in the theory, algorithm, education and applications of information technology" (2013), "Stefan Odobleja" Award in Information Science and Technology from the Academy of Scientists for the book Optimization dans les sciences de l'ingenieur (2015). 


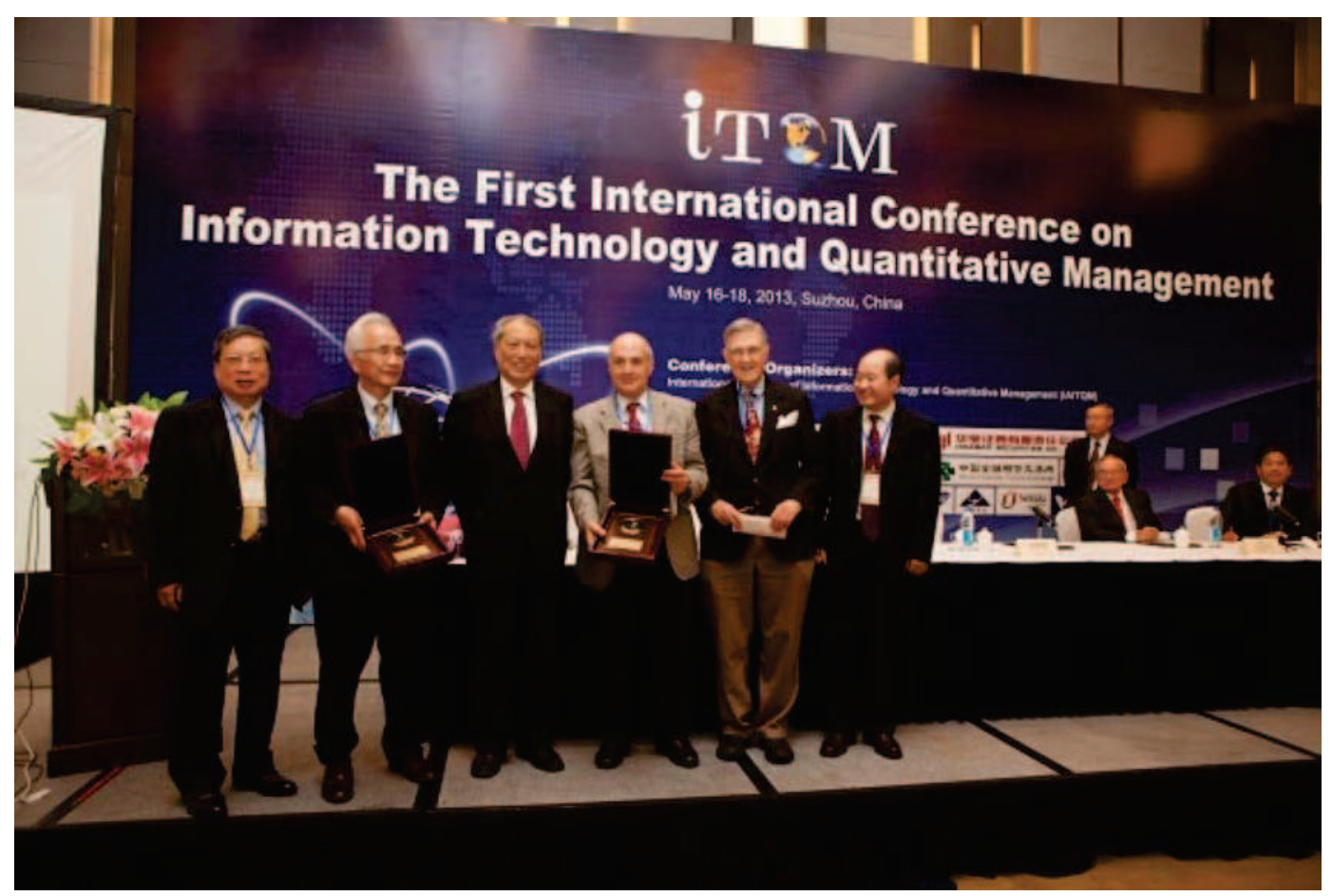

"Walter Scott Jr. in IT Award" for F.G. Filip by the IAITQM at ITQM2013, Suzhou, China (Anonymous Sponsor), Cheng-Few Lee, Cheng Siwei, Florin Gheorghe Filip, Daniel Berg, Yong Shi

\section{Publications}

\subsection{Published books (monographs and volumes)}

F.G. Filip is author/co-author of 13 monographs, and edited/co-edited 24 contributed volumes, such as: [2], [17], [18], [20], [34], [35], [43], etc.

The summary of the monograph Computer-Supported Collaborative Decision-Making [34] is presented at Springer web page [45]:

Addresses specific concepts, technologies, and systems for collaborative activities with particular emphasis on decision-making;

Balanced presentation of well consolidated and modern methodologies, together with pacing information and communications;

Includes various industrial, financial and "culture economy" applications.

"This is a book about how management and control decisions are made by persons who collaborate and possibly use the support of an information system. The decision is the result of human conscious activities aiming at choosing a course of action for attaining a certain objective (or a set of objectives). The act of collaboration implies that several entities who work together and share responsibilities to jointly plan, implement and evaluate a program of activities to achieve the common goals.

The book is intended to present a balanced view of the domain to include both well-established concepts and a selection of new results in the domains of methods and key technologies. It is meant to answer several questions, such as:

a) How are evolving the business models towards the ever more collaborative schemes?;

b) What is the role of the decision-maker in the new context?;

c) What are the basic attributes and trends in the domain of decision-supporting information systems?; 


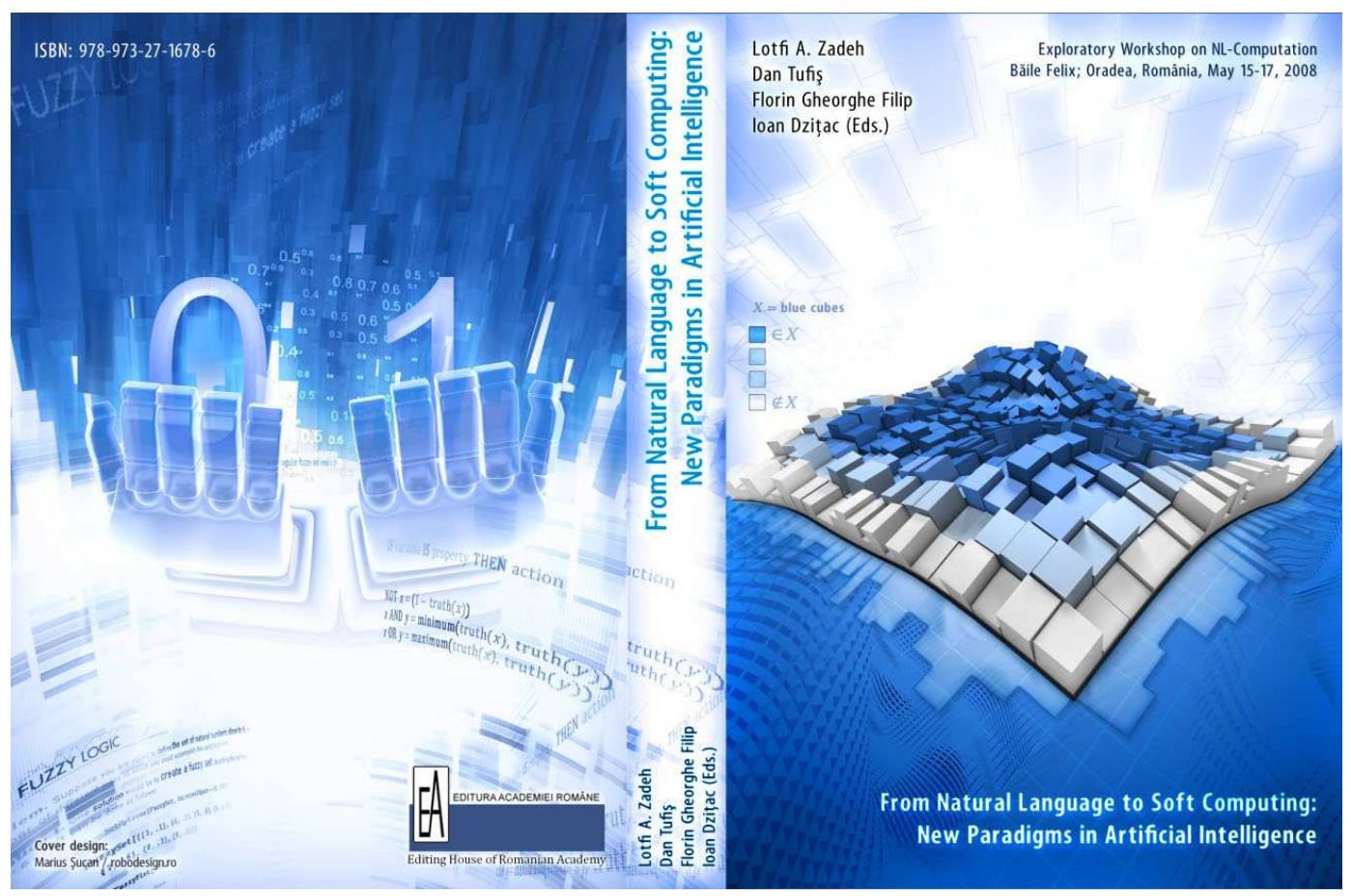

Volume co-edited with L.A. Zadeh, D. Tufis and I. Dzitac (2008, Romanian Academy) [43]

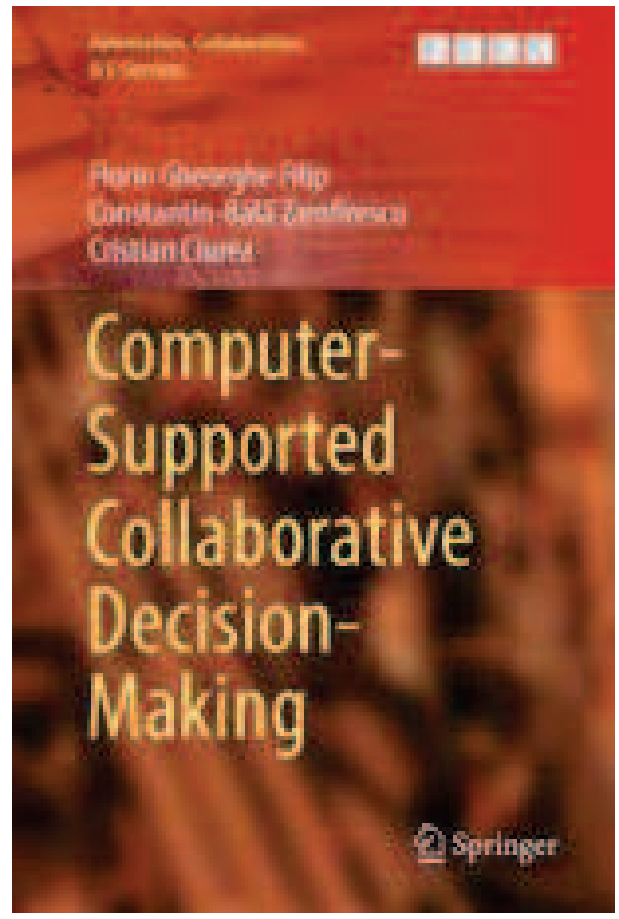

Monograph co-authored with C.B. Zamfirescu and C. Ciurea (2016, Springer) [34] 
d) Which are the basic methods to aggregate the individual preferences?;

e) What is the impact of modern information and communication technologies on the design and usage of decision support systems for groups of people?"

\subsection{Most cited papers}

Florin Gheorghe Filip has authored/co-authored over 300 scientific papers. For example, some selected papers authored by F.G. Filip are [9] - [16] or co-authored with other international scientists [3]- [7], [19], [21]- [25], [27] - [38], [40], [41], etc.

Only in Web of Science - Core Collection, the papers authored/co-authored by F.G. Filip has been cited over 200 times.

The most cited paper authored by F.G. Filip is Decision support and control for large-scale complex systems [15]. This paper has been cited in a lot important international journals, indexed in Web of Science, such as: Robotics and Autonomous Systems, Information Sciences, International Journal of Systems Science, Technological and Economic Development of Economy, IEEE Transactions on Industrial Electronics, Studies in Informatics and Control, Romanian Journal of Information Science and Technology, Quality and Reliability Engineering International, Biometric and Intelligent Decision Making Support, International Journal of Computers Communications $\& 3$ Control, Simulation Modelling Practice and Theory, and others.

Many citations in Web of Science has also other papers such as: A Decision-Making Perspective for Designing and Building Information Systems [16], Job Shop Scheduling Optimization in Real-Time Production Control [29], DSS in Numbers [33], Multilevel optimization algorithms in computer-aided production control in process industry [23], etc.

\section{Science and research management}

1. Management of ICI (National Institute of Informatics) during 1991-1997, as a directorgeneral. At the time, ICI obtained about $50 \%$ of the IT research projects funded by the European Commission and it was placed (in 1997) first among the most famous 10 research institutes in Romania in the Report of the Coopers \& Lybrand Company Consortium, submitted to the European Commission. In 1992, ICI team introduced Internet into the country through the RNC network 1992;

2. He was part of the first team of the five evaluators from Romania for the project proposals for the EU research program called EC-PECO (European Commission - Pays de l'Europe Centrale et Orientale) in 1992;

3. He introduced the Romanian research funding system through competition in the field of "Informatics" (1992) and co-founder and deputy chair (1996-2003) of the Council for the Romanian Academy Grants;

4. He was the Secretary General of the Romanian National Advisory Council for ResearchDevelopment, and Innovation (1997-2010);

6. Member in the "IST Prize" jury, organized by EUROCASE (Federation of academies of Applied and Engineering Sciences in Europe) for 10 years (1997-2007);

7. The first Romanian scientist in the IT Advisory Group (ISTAG) of the European Commission (2001), and NATO Science for Peace subcommittee for "Computer Networks" (2000).

\section{$5 \quad$ Editorial activities}

Acad. Filip is a member in the editorial staff of several scientific journals, such as: 1. Systems Analysis, Modeling and Simulation (Taylor and Francis, 1993-2004); 
2. International J. of Critical Infrastructures (Inderscience Publishers, since 2004);

3. Computer Journal of Moldova (Chisinau, since 1993);

4. Information Technologies and Control (Sofia, since 1998);

5. Romanian Journal of Information Science and Technology (Romanian Academy);

6. Studies in Informatics and Control (ICI, founder and chief-editor, from 1989);

7. International Journal of Computers Communications \& Control (Agora Univ., chief-editor from 2006);

8. Control Engineering and Applied Informatics (SRAIT);

9. Romanian Journal of Informatics and Automatics (ICI, founder;

10. Romanian Journal of Automatics;

11. Technological and Economic Development of Economy (Taylor \& Francis);

12. International Journal of Information Technology \& Decision Making (Science Direct);

13. Advances in Electrical and Computer Engineering (Stefan Cel Mare Univ.);

14. Financial Innovation (Springer, since 2016);

15. Journal of System and Management Sciences (Beijing Jiatong Univ., China).

F.G.Filip is the founder and Editor-in-Chief of Studies in Informatics and Control (1991), and co-founder and Editor-in-Chief of International Journal of Computers Communications \& Control (2006).

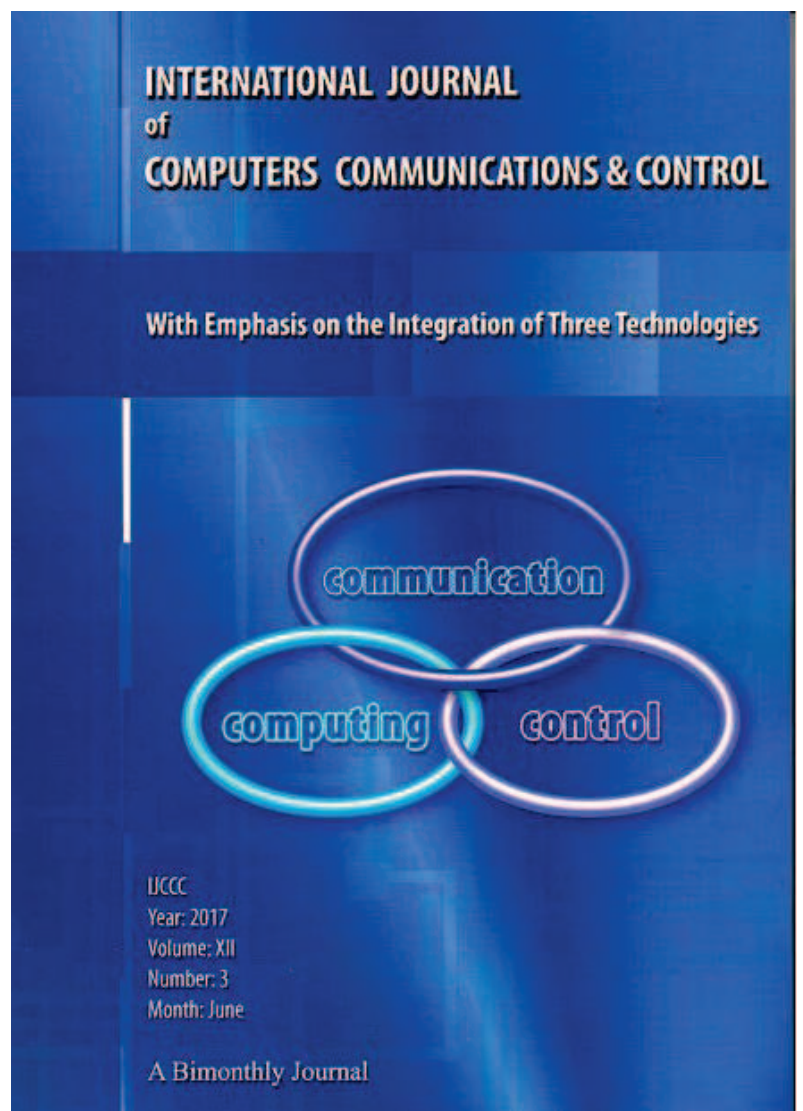

International Journal of Computers Communications \& Control

(Founded in 2006 at Agora University by I. Dzitac, F.G. Filip, M.J. Manolescu) 


\section{Conclusion}

Florin Gheorghe Filip authored/co-authored over 300 papers published in international journals (IFAC J. Automatica, IFAC J. Control Engineering Practice, Annual Reviews in Control, Computers in Industry, Large Scale Systems etc.) and contributed volumes released by international publishing houses (Pergamon Press, North Holland, Elsevier, Kluwer, Chapman \& Hall and so on). He is also the author/co-author of 13 monographs (published by Editura Tehnică Bucharest, Hermes-Lavoisier - Paris, J. Wiley \& Sons London, Springer) and editor/co-editor of 24 volumes of contributions (published by Editing House of the Romanian Academy, Pergamon Press, Elsevier, Institute of Physics Melville - USA, IEEE Computer Society - Los Alamitos USA). His main scientific contributions include: hierarchical optimization and control of largescale systems, decision support systems (DSS), applications of IT in the cultural sector, technology management and foresight. In our bibliographic list are presented 42 selected works (papers, monographs, volumes) authored/co-authored by F.G. Filip [2-7], [9-44].

Acad. Filip have a good international impact and many collaborators, from countries such as: Brazil (L.F. Autran Monteiro Gomes), Bulgaria (K. Boyanov, B. Sendov), Chile (F. Cordova, C. Lagos, G. Lefranc), China (G. Kou, Y. Peng, C. Siwei, Y. Shi, M. Tang), Czech Republic (K. Bakule, J. Zavorka), Finland (K. Leiviskä), France (J. Bernussou, P. Borne, A. Dolgui, A. El Kamel, H. Panetto, A. Titli, P. Zarate), Germany (R. Popescu-Zeletin, K. Reinisch, A. Sydow), Greece (P. Groumpos, G. Metakides, P. Spirakis), Hungary (G. Kovacs, L. Monostori), Lithuania (G. Dzemyda, A. Kaklauskas, Z. Turskis, E.K. Zavadskas), Mexic (A. Molina), Poland (W. Findeisen. M.A. Brdys, K. Malinowski), Portugal (A.D. Correia, L.M. Camarinha Matos), Republic of Moldova (G. Căpăţănă, I. Cojocaru, S. Cojocaru, G. Duca, C. Gaindric), Romania (B. Bărbat, V. Balas, M. Bizoi, G. Bologa, I. Buciu, C. Ciurea, H. Dragomirescu, M. Guran, D. Donciulescu, I. Dumitrache, I. Dzitac, E.A. Iancu, A. Ionita, I. Ivan, R. Lile, A. Manolescu, M.J. Manolescu, I. Moisil, G. Neagu, S. Nicoară, S.I. Niţchi, H. Oros, N. Paraschiv, D. Popescu, R.E. Precup, O Proştean, D. Ştefănoiu, A.M. Suduc, H.N. Teodorescu, D. Tufiş, C.B. Zamfirescu), Russia (F. Aleskerov), Spain (E. Herrera -Viedma, A. Ortiz), Sweden (A. Hedin), UK (P.D. Roberts), and from USA (R. Andonie, D. Berg, S.M. Gupta, S.Y. Nof, D.J. Power, G. Tecuci, T.J. Williams, A.B. Whinston, L.A. Zadeh).

We cannot come to an end without mentioning the man Florin Gheorghe Filip. All of us that know him, if asked which are the first three words coming in our minds we shall not hesitate to tell: intuitive, generous and catalyst. He is able to intuit a young researcher, a valuable research team or an academic institution with prospects. Full of modesty, he does not know envy and is always eager to support those needing his advices, with a generosity specific to great spirits. His behavior is always of a catalyst, precipitating many beneficial reactions, support without waiting for a reward.

\section{Acknowledgment}

We are honoured and we grateful to Prof. Filip for his contributions, in his capacity of Editorin-Chief, of our International Journal of Computers Communications \& Control (co-founded in 2006 with I. Dzitac and M.J. Manolescu at Agora University in Oradea, Romania). 


\section{Bibliography}

[1] Bărbat B.E. (2007), Filip the Catalyst, The Computer Science Journal of Moldova, 15(2), 115-119, 2007.

[2] Borne P., Popescu D., Filip F.G., Ştefanoiu D. (2012), Optimisation en sciences de l'ingenieur, Hermes-Lavoisier, Paris, 2012 (in French).

[3] Brândaş C., Panzaru C., Filip F. G. (2016), Data driven decision support systems: an application case in labour market analysis, Romanian Journal of Information Science and Technology, 19(1-2), 65-77, 2016.

[4] Cândea C., Filip F.G. (2016), Towards intelligent collaborative decision support platforms, Studies in Informatics and Control, 25(2), 143-152, 2016.

[5] Duţă L., Filip F.G., Henrioud J.M.(2003), A method for dealing with multi-objective optimization problem of disassembly processes, Assembly and Task Planning, 2003. Proceedings of the IEEE International Symposium, 163-168, 2003.

[6] Duţă L; Filip F.G., (2008), Control and Decision-making Process in Disassembling Used Electronic Products, Studies in Informatics and Control, 17(1), 17-26, 2008.

[7] Duţă L., Filip F.G., Popescu C. (2008), Evolutionary programming in disassembly decision making International Journal of Computers Communications \& Control, 3(Supll.), 282-286, 2008 .

[8] Dzitac I., Manolescu M.J., Oros H., Văleanu E. (2007); 60 Years from Birth of Academician F.G. Filip, International Journal of Computers Communications \& Control, 2(3), 209-216 , 2007.

[9] Filip F.G. (1989), Creativity and decision support systems, Studies and Researches in Computer and Informatics, 1(1), 41-49, 1989.

[10] Filip F.G. (1991), System analysis and expert systems techniques for operative decision making, Systems Analysis Modeling Simulation, Gordon and Breach Science Publishers, 8(3), 213-219, 1991.

[11] Filip F.G. (1994), Evolutions in systems analysis, modelling and simulation in Computer based industrial automation, Systems Analysis, Modelling and Simulation, 15, 135-149, 1994.

[12] Filip F.G. (1995), IT culture dissemination in Romania: experiments and achievements, In A. Inzelt and R. Coenen (Eds.), Knowledge Technology Transfer and Forecasting, Kluwer Academic, Dordrecht, 149-160, 1995.

[13] Filip F.G. (1995), Towards more humanized DSS, In: L.M. Camarinha Matos and H. Afsarmanesh (Eds.), Balanced Automation Systems: Architectures and Design Methods, Chapmann \& Hall, London, 230-240, 1995.

[14] Filip F.G. (1998), Optimization models with sparse matrices and relatively constant parameters, Systems Analysis Modelling and Simulation, 33, 407-430, 1998.

[15] Filip F.G. (2008), Decision support and control for large-scale complex systems, Annual Reviews in Control, 32(1), 61-70, 2008. 
[16] Filip F.G. (2012), A Decision-Making Perspective for Designing and Building Information Systems, International Journal of Computers Communications \& Control, 7(2), 264-272, 2012.

[17] Filip F.G. (2002), Decizie asistată de calculator decizii, decidenți, metode şi instrumente de bazăa, Editura Tehnică, Bucureşti, 2002 (in Romanian).

[18] Filip. F.G. (2007), Sisteme suport pentru decizii, Editura Tehnică, Bucureşti, 2007 (in Romanian).

[19] Filip F.G., Alexandru A., Socol I. (1997), Technology management and international cooperation: several success stories, J. Human Systems Management, 16, 223-229, 1997.

[20] Filip F.G., Bărbat B. (1999), Informatică industrială: Noi paradigme şi aplicaţii, Editura Tehnică, Bucureşti, 1999 (in Romanian).

[21] Filip F.G., Ciurea C., Dragomirescu H., Ivan I. (2015), Cultural heritage and modern information and communication technologies, Technological and Economic Development of Economy, 21(3), 441-459, 2015.

[22] Filip F.G., Donciulescu D. A. , Filip C.I. (2001), A cybernetic model of computerization of the cultural heritage, Computer Science Journal of Moldova, 9(2), 101 -112, 2001.

[23] Filip F.G. , Donciulescu D.A., Gaşpar R., Muratcea M., Orăşanu L. (1985), Multilevel optimization algorithms in computer-aided production control in process industry, Computers in Industry, 6(1), 47-57, 1985.

[24] Filip F.G., Donciulescu D.A. (1983), On on-line direct dynamic coordination method in process industry, IFAC J. Automatica, Pergamon Press, Oxford, 19(1), 317 - 320, 1983.

[25] Filip F.G., Dragomirescu H., Predescu R., Ilie R. (2004), IT tools for foresight studies, Studies in Informatics and Control, 13(3), 161-168, 2004.

[26] Filip F.G., Dumitrache I., Iliescu S.S. (Eds.) (2002), Large Scale Systems: Theory and Applications, Elsevier Science Ltd. (Pergamon), Oxford, 2002.

[27] Filip F.G., Herrera-Viedma E. (2014), Big data in the European Union, The Bridge, 44(4), 33-37, 2014.

[28] Filip F.G., Leiviskä K. (2009), Large-scale complex systems, In: Nof S.Y. (Ed.), Springer Handbook of Automation, Springer, Berlin Heidelberg, 619-638, 2009.

[29] Filip F.G., Neagu G., Donciulescu D. (1983), Job Shop scheduling optimisation in real-time production control, Computers in Industry, 4(4), 395-403, 1983.

[30] Filip F.G., Neagu G., Donciulescu D. (1996), DSSfM: from technology to decision making, Proceedings 14th IFAC World Congress, San Francisco, Vol B, 367-372, 199

[31] Filip F.G., Neagu G. (1993), CIM in continuous and discrete manufacturing: object-oriented generic modeling, IFAC J.Control Eng. Practice, 1(5), 815-825, 1993.

[32] Filip F.G., Popescu D., Mateescu M. (2008), Optimal decisions for complex systems-software packages, Mathematics and Computers in Simulation, 76(5-6), 422-429, 2008.

[33] Filip F.G., Suduc A.M., Bizoi M. (2014), DSS in Numbers, Technological and Economic Development of Economy, 20(1), 154-164, 2014. 
[34] Filip F.G., Zamfirescu C.B., Ciurea C. (2016), Computer-Supported Collaborative DecisionMaking, Springer, 2016.

[35] Guran M., Filip F.G. (1986), Sisteme ierarhizate şi în timp real cu prelucrarea distribuită a datelor, Editura Tehnică, Bucureşti, 1986 (in Romanian).

[36] Guran M., Filip F.G., Donciulescu D., Orăşanu L. (1985), Hierarchical optimization in computer-aided dispatcher systems in the process industry, Large scale systems, 8(2), 157$167,1985$.

[37] Nicoară E.S., Filip F.G., Paraschiv N. (2011), Simulation-based Optimization Using Genetic Algorithms for Multi-objective Flexible JSSP, Studies in Informatics and Control, 20(4), 333-344, 2011.

[38] Nof S.Y., Morel G., Monostori L., Molina A., Filip F.G. (2006), From plant and logistics control to multi-enterprise collaboration, Annual Reviews in Control, Elsevier, 30(1), 55-68, 2006 .

[39] Pascu C., Filip F.G. ( Eds.) (2005); Visions on Information Society Future in an Enlarged Europe, Editura Academiei, Bucureşti, 2005.

[40] Seok H., Nof S.Y., Filip F.G. (2012), Sustainability decision support system based on collaborative control theory Annual Reviews in Control, 36(1), 85-100, 2012.

[41] Reşteanu C., Filip F.G., Ionescu C., Somodi M. (1996), On optimal choice problem solving, In: Systems, Man, and Cybernetics, 1996, IEEE International Conference, 3, 1864-1869, 1996.

[42] Ştefanoiu D., Borne P., Popescu D., Filip F.G., El Kamel A. (2014), Optimization in Engineering Sciences: Approximate and Metaheuristic Methods, John Wiley \& Sons, London, 2014.

[43] Zadeh L.A., Tufiş D., Filip F.G., Dzitac I. (Eds.) (2008), From Natural Language to Soft Computing: New Paradigms in Artificial Intelligence, Editing House of the Romanian Academy, 2008.

[44] Zamfirescu C.B., Filip F.G. (2010), Swarming Models for Facilitating Collaborative Decisions International Journal of Computers Communications \& Control, 5(1), 125-137, 2010.

[45] http://www.springer.com/gp/book/9783319472195 